\title{
IN VITRO ANTHELMINTIC ACTIVITY OF MAYTENUS EMARGINATA STEM BARK ON INDIAN ADULT EARTHWORM
}

\author{
UMESH PRABHAKAR JOSHI*, RAJENDRA DAYARAM WAGH \\ Department of Pharmacognosy, DCS's ARA College of Pharmacy, Nagaon, Dhule - 424 006, Maharashtra, India. \\ Email: joshiup2008@gmail.com
}

Received: 14 November 2018, Revised and Accepted: 31 December 2018

\begin{abstract}
Objective: The development of anthelmintic activity and the high cost of synthetic anthelmintic drugs it leads to the evaluation of medicinal plants as an alternative source of anthelmintics. In the current study, in vitro experiments were conducted to determine the possible anthelmintic effects of crude methanolic, aqueous, and hydroalcoholic extracts of the stem bark of Maytenus emarginata on eggs and adult Pheretima posthuma and Ascaridia galli.
\end{abstract}

Methods: Three concentrations $(10,25$, and $50 \mathrm{mg} / \mathrm{ml})$ of methanolic, aqueous, and hydroalcoholic extracts of plant $M$. emarginata were studied in activity which involved the determination of the time of paralysis (called as vermifuge) and time of death (called as vermicidal) of the worms. Piperazine citrate in same concentration as those of extract was included as standard reference and normal saline water with $1 \%$ carboxymethyl cellulose as control.

Results: The methanolic, aqueous, and hydroalcoholic extracts exhibited significant anthelmintic activity at a concentration of 50 mg/ml. Peak activity was exhibited by the methanolic extract at a concentration of $50 \mathrm{mg} / \mathrm{ml}$.

Conclusion: The overall findings of the present study have shown that M. emarginata contain possible anthelmintic compounds and further evaluation of these plants should be carried out. The traditional use of anthelmintic activity of this plant is genuine.

Keywords: Anthelmintic activity, Maytenus emarginata, Pheretima posthuma (Annelida), Ascaridia galli, Piperazine citrate, Helminthiasis.

(C) 2019 The Authors. Published by Innovare Academic Sciences Pvt Ltd. This is an open access article under the CC BY license (http://creativecommons. org/licenses/by/4. 0/) DOI: http://dx.doi.org/10.22159/ajpcr.2019.v12i3.30756

\section{INTRODUCTION}

Helminth parasite infection is one of the most major global problems with serious social and causes economic impact in the third world countries including India. Global estimates have found out that many of peoples all over the world are infected by helminth parasites [1]. Parasitic infection including helminthiasis is a critical serious problem in the tropical regions including the Asian and African countries which affects more than 2.5 billion of people worldwide [2]. Different type of helminths infects the human and animals, of which intestinal roundworms Pheretima posthuma (Annelida) are most common. Variety of several clinical symptoms arises due to this infection includes dysentery, diarrhea, nausea, vomiting, loss of appetite, loss of weight, acidity, and anemia. Other signs and symptoms of helminthic infections include respiratory symptoms, dermatological consequences, and epilepsy as a result of neurocysticercosis. Helminthic infections may also subvert immune responses to pathogens of other diseases such as tuberculosis, HIV, and malaria [3]. Helminthiasis is a disease in which part of human body is infested with worms such as flatworms, roundworms, and roundworm or tapeworm. Typically, the worms present in the gastrointestinal tract but may also reside into the liver and other organs, infected peoples are excreted helminth eggs in their feces, which then contaminate the soil in areas with inadequate sanitation [4]. Other peoples can be infected by ingesting eggs or larvae in contaminated food or through penetration of the skin by infective larvae in the soil (hookworms). Parasitic diseases can cause severe morbidity including filariasis (a cause of elephantiasis), onchocerciasis (river blindness), and schistosomiasis [5]. As per the WHO, some synthetic drugs are sometimes used in the treatment of helminth infection in human beings, but these synthetic drugs are out of reach of millions of people and may have many side effects. Due to this, an attempt has been made to study the anthelmintic activity of herbal drug. Development of resistance to most of the commercially available anthelmintics drugs is became a severe problem worldwide [6]. Screening and proper evaluation of the claimed medicinal plants anthelmintics could offer possible alternatives that may be both sustainable and environmentally acceptable. Maytenus emarginata is an evergreen tree that tolerates various types of stresses of the desert. It is commonly known as Thorny staff tree in English and Kankero in Hindi. The plant is very popular and well known for its vermifuge, toothache, cooling effects, purify blood, fever, asthma, rheumatism, and gastrointestinal disorders worldwide [7]. In the current study, we have attempted to investigate methanolic, hydroalcoholic, and aqueous extracts of the stem bark of medicinal plant M. emarginata for their claimed anthelmintic activity.

\section{METHODS}

\section{Plant collection}

The fresh stem barks of plant $M$. emarginata were collected from Haripura and Manudevi region of Taluka Yawal, District Jalgaon, India. The selected plants were authenticated by Dr. D. A. Dhale, Asst. Professor, PG, and Research Department of Botany SSVPS's, L. K. Dr. P. R. Ghogrey Science College, Dhule, Maharashtra. Stem barks were dried at room temperature to avoid loss of chemical constituents and milled with the aid of grinding machine.

\section{Selection of experimental worms}

Indian adult earthworms such as P. posthuma and Ascaridia galli were used to carry out the anthelmintic activity. P. posthuma is commonly known as earthworm and were collected from waterlogged areas. A. galli is nematode and were obtained from freshly slaughtered area. Both worms were identified by the PG Department of Zoology, SSVPS's Science College, Dhule. Worms were washed with normal saline to remove all fecal matters. The earthworms of 7-9 $\mathrm{cm}$ in length and $0.2-0.4 \mathrm{~cm}$ in width were used for all the experimental protocol. Ready availability, anatomical 
and physiological resemblance of $P$. posthuma and A. galli made it to be used initially for in vitro evaluation of anthelmintic activity.

\section{Preparation of plant extract}

The stem bark of plant was thoroughly washed with tap water, dried at room temperature, and transformed to coarse powder. The stem bark powder was extracted with three solvents, i.e., methanol, water, and water-ethanol separately by Soxhlet extraction method. Finally, all the extracts were evaporated and dried under vacuum or tray dryer to obtain thick sticky extract.

\section{Drugs and chemicals}

Piperazine citrate (Actipar Syrup), methanol, distilled water, and ethanol were used during the experimental protocol. All the chemicals used are belonging to laboratory and analytical grade.

\section{Experimental work [8-11]}

The anthelmintic activity was carried out on earthworms which is well explained by Ajaiyeoba et al., 2001, with minor modifications. The assay was performed on adult Indian earthworm P. posthuma and A. galli due to their anatomical and physiological resemblance with the intestinal roundworm parasite of human being $[12,13]$. Due to easy availability, earthworms have been used widely for initial evaluation of anthelmintic compounds in vitro. The Indian earthworm P. posthuma and A. galli, of nearly equal size, six in each group, was taken for the experiment. The methanolic, aqueous, and hydroalcoholic dried extract were suspended in $1 \% \mathrm{w} / \mathrm{v}$ carboxymethyl cellulose, prepared in normal saline water in three different conc. $(10,25$, and $50 \mathrm{mg} / \mathrm{ml})$. Piperazine citrate suspension of the concentration of $10 \mathrm{mg} / \mathrm{ml}$ was taken as standard, and normal saline water with $1 \%$ carboxymethyl cellulose was taken as a control. Worms were placed in Petri dish containing $25 \mathrm{ml}$ of sample (drug) solution. Time for paralysis was noted and observations are made by any movement could not be seen except when the worms were shaken vigorously or when dipped in warm water $\left(60^{\circ} \mathrm{C}\right)$. Death was included when the worms lost their motility followed by white secretions and fading away of their body color.

\section{Statistical analysis [14]}

The data presented as mean \pm standard error of the mean. The activities of both the leaf extracts were compared with the control. All the plant extracts showed significant duration of paralysis and death. Values of $\mathrm{p}<0.001$ were considered statistically significant.

\section{RESULTS AND DISCUSSION}

Preliminary phytochemical screening of methanolic, aqueous, and hydroalcoholic extract of stem bark of plant M. emarginata was revealed the presence of glycosides, alkaloids, saponins, flavonoids, and tannins. As shown in Tables 1 and 2, methanolic extract exhibited anthelmintic activity in dose-dependent manner giving shortest time of paralysis (P) and death (D) with $50 \mathrm{mg} / \mathrm{ml}$ concentration, for P. posthuma and A. galli worms. The methanolic, aqueous, and hydroalcoholic extracts showed paralysis followed by death of the worms at all tested dose levels. The potency of the extracts was found inversely proportional to the time taken for paralysis of death of worms.

The methanolic extract of the stem bark of plant M. emarginata time of paralysis is $9.36 \mathrm{~min}$ and time of death is $23.43 \mathrm{~min}$, and hydroalcoholic extract revealed that the time of paralysis is $18.88 \mathrm{~min}$ and time

Table 1: Anthelmintic activity of methanolic, aqueous, and hydroalcoholic extract of the stem bark of plant Maytenus emarginata on Pheretima posthuma

\begin{tabular}{llll}
\hline Extract & Concentration mg/ml & \multicolumn{2}{l}{ Pheretima posthuma } \\
\cline { 2 - 3 } & & Time of paralysis (P) & Time of death (D) \\
\hline Control 1\% CMC & ----- & - \\
Standard (Piperazine citrate) & $10 \mathrm{mg} / \mathrm{ml}$ & $2.5 \pm 0.13$ & $16.23 \pm 0.58$ \\
Methanolic extract & $10 \mathrm{mg} / \mathrm{ml}$ & $26.62 \pm 0.18$ & $42.55 \pm 0.64$ \\
& $25 \mathrm{mg} / \mathrm{ml}$ & $16.69 \pm 0.43$ & $35.46 \pm 0.55$ \\
Hydroalcoholic extract & $50 \mathrm{mg} / \mathrm{ml}$ & $9.36 \pm 0.29$ & $23.43 \pm 0.21$ \\
& $10 \mathrm{mg} / \mathrm{ml}$ & $38.25 \pm 0.45$ & $51.54 \pm 0.53$ \\
Aqueous extract & $25 \mathrm{mg} / \mathrm{ml}$ & $28.39 \pm 0.28$ & $40.58 \pm 0.61$ \\
& $50 \mathrm{mg} / \mathrm{ml}$ & $18.88 \pm 0.18$ & $28.10 \pm 0.37$ \\
& $10 \mathrm{mg} / \mathrm{ml}$ & $46.02 \pm 0.56$ & $68.02 \pm 0.32$ \\
& $25 \mathrm{mg} / \mathrm{ml}$ & $39.51 \pm 0.31$ & $57.59 \pm 0.50$ \\
\hline
\end{tabular}

All values represent Mean \pm SEM; $n=6$ in each group. Comparisons made between standard versus treated groups, $p<0.05$ was considered statistically significant.

SEM: Standard error of the mean

Table 2: Anthelmintic activity of methanolic, aqueous, and hydroalcoholic extract of the stem bark of plant Maytenus emarginata on Ascaridia galli

\begin{tabular}{lll}
\hline Extract & Concentration mg/ml & \multicolumn{1}{l}{ Ascaridia galli } \\
\cline { 2 - 3 } & & Time of paralysis (P) \\
\hline Control 1\% CMC & -- & -- \\
Standard (Piperazine citrate) & $10 \mathrm{mg} / \mathrm{ml}$ & $3.67 \pm 0.35$ \\
Methanolic extract & $10 \mathrm{mg} / \mathrm{ml}$ & $28.14 \pm 0.28$ \\
& $25 \mathrm{mg} / \mathrm{ml}$ & $18.43 \pm 0.38$ \\
Hydroalcoholic extract & $50 \mathrm{mg} / \mathrm{ml}$ & $12.55 \pm 0.40$ \\
& $10 \mathrm{mg} / \mathrm{ml}$ & $40.45 \pm 0.68$ \\
Aqueous extract & $25 \mathrm{mg} / \mathrm{ml}$ & $27.37 \pm 0.28$ \\
& $50 \mathrm{mg} / \mathrm{ml}$ & $20.90 \pm 0.19$ \\
& $10 \mathrm{mg} / \mathrm{ml}$ & $47.63 \pm 0.38$ \\
\hline
\end{tabular}

All values represent Mean \pm SEM; $n=6$ in each group. Comparisons made between standard versus treated groups, $p<0.05$ was considered statistically significant.

SEM: Standard error of the mean 


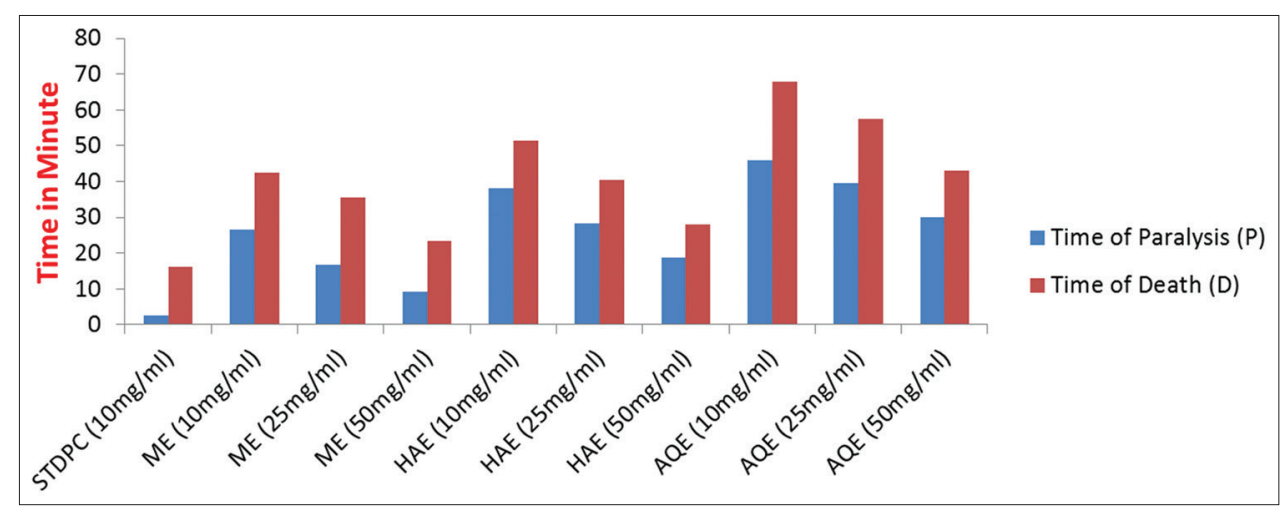

Fig. 1: Anthelmintic activity of Maytenus emarginata stem bark on Pheretima posthuma. Where, STDPC - Standard Piperazine citrate, ME - Methanolic extract, HAE - Hydroalcoholic extract, AQE - Aqueous extract

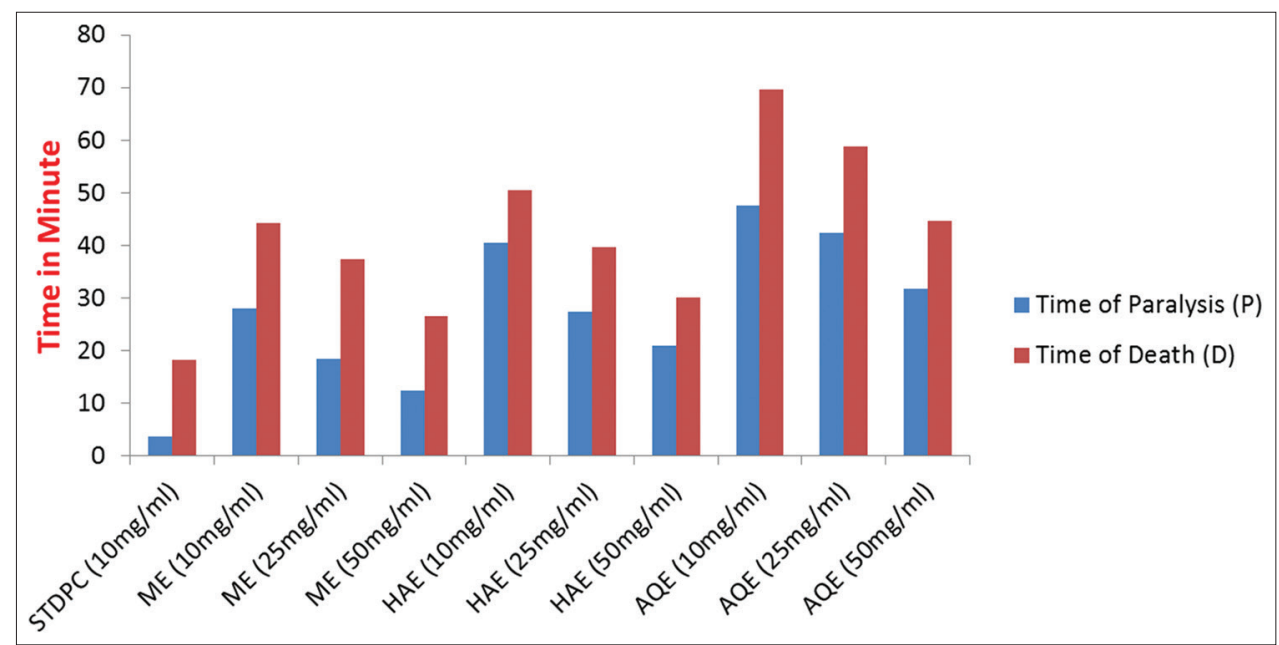

Fig. 2: Anthelmintic activity of Maytenus emarginata stem bark on Ascaridia galli. Where, STDPC - Standard Piperazine citrate, ME - Methanolic extract, HAE - Hydroalcoholic extract, AQE - Aqueous extract

of death is 28.10 min while aqueous extract revealed that time of paralysis is $30.04 \mathrm{~min}$ and time of death is $42.98 \mathrm{~min}$, respectively, against $P$. posthuma at $50 \mathrm{mg} / \mathrm{ml}$ concentration. The reference drug piperazine citrate showed that the time of paralysis is $2.5 \mathrm{~min}$ and time of death at concentration of $10 \mathrm{mg} / \mathrm{ml}$ is $16.23 \mathrm{~min}$, respectively. The methanolic extract of the stem bark of plant M. emarginata paralysis is $12.55 \mathrm{~min}$ and time of death is $26.64 \mathrm{~min}$ and hydroalcoholic extract revealed paralysis of $20.90 \mathrm{~min}$ and time of death $30.13 \mathrm{~min}$ while aqueous extract revealed paralysis of $31.84 \mathrm{~min}$ and time of death $44.77 \mathrm{~min}$, respectively, against $A$. galli at $50 \mathrm{mg} / \mathrm{ml}$ concentration. The reference drug piperazine citrate showed the paralysis at $3.67 \mathrm{~min}$ and time of death at $10 \mathrm{mg} / \mathrm{ml}$ conc. $18.29 \mathrm{~min}$, respectively.

Piperazine citrate by increasing chloride ion conductance in worm muscle membrane produces hyperpolarization and reduced excitability that leads to muscle relaxation and flaccid paralysis [15]. The extracts of the stem bark of plant $M$. emarginata not only demonstrated paralysis but also caused death of worms, especially at higher concentration of $50 \mathrm{mg} / \mathrm{ml}$, in shorter time as compared to reference drug piperazine citrate. Phytochemical screening of the extracts revealed the presence of tannins among the other chemicals constituent within them. The chemical constituent tannins were shown to produce anthelmintic activities [16]. Chemically, tannins are polyphenolic compounds [17]. Some synthetic phenolic anthelmintics, for example, albendazole, niclosamide, oxyclozanide, bithionol, etc., are reported to interfere with energy generation in helminth parasites by uncoupling oxidative phosphorylation [18]. It is possible that tannins contained in the extracts of the stem bark of plant M. emarginata produced similar effects. Another possible anthelmintic effect of tannins is that they can be bind to free proteins in the gastrointestinal tracts of host animal [19] or glycoprotein on the cuticle of the parasite [20] and may cause death.

The traditional medicinal plants hold a great promise as source of easily available effective anthelmintic agents to the people, particularly in developed and developing countries, including in India, Pakistan, Sri Lanka, and Bhutan. It is, in this context, that the people consumed several plants or plant-based preparation to cure helminthic infections [21]. The origin of many effective herbal drugs has been found in the traditional medicines practices and in view of this, it is important to undertake studies pertaining to screening of the folklore medicinal plants for their claimed anthelmintic efficacy (Figs. 1 and 2).

- CMC - Carboxymethyl cellulose

\section{CONCLUSION}

The results of the present study clearly indicated that the methanolic extract of plant $M$. emarginata produces anthelmintic activity against Indian earthworm $P$. posthuma and A. galli. The plant possesses significant anthelmintic activity at $50 \mathrm{mg} / \mathrm{ml}$ concentration measured by time taken for paralyze and death of the earthworms. The current investigation leads to conclusion that the stem bark of plant M. emarginata has potent anthelmintic activity when compared with the conventionally used drug. Further studies can be explore using in vivo models and to carry isolation of active constituents from methanolic extract and establishment of the effectiveness and pharmacological rationale for the use of plant M. emarginata as an anthelmintic drug. 


\section{ACKNOWLEDGMENT}

The corresponding author is very grateful to Principal and my PhD guide, Dr. Rajendra D. Wagh, DCS’s A.R.A. College of Pharmacy, Nagaon, Dhule, for providing necessary facilities, support, and proper guidance throughout the research work.

\section{AUTHORS' CONTRIBUTIONS}

We declare that this work was done by the corresponding author named in this article under the guidance of Dr. Rajendra Dayaram Wagh and all liabilities pertaining to claims relating to the content of this article will be borne by the corresponding author. Mr. Joshi Umesh Prabhakar collected the data and analyzed the data. Dr. Rajendra Dayaram Wagh who make proofread the whole manuscript and suggested the necessary changes and helped in developing the manuscript.

\section{CONFLICTS OF INTEREST}

The authors declare that there are no conflicts of interest regarding the publication of this paper.

\section{REFERENCES}

1. Swargiary A, Roy B. In vitro anthelmintic efficacy of Alpinia nigra and its bioactive compound, astragal in against Fasciolopsis buski. Int $\mathrm{J}$ Pharm Pharm Sci 2015;7:30-5.

2. Hossain E, Chandra G, Nandy AP, Mandal SC, Gupta JK. Anthelmintic effect of a methanol extract of leaves of Dregea volubilis on Paramphistomum explanatum. Parasitol Res 2012;110:809-84.

3. Tripathi KD. Essentials of Medical Pharmacology. $6^{\text {th }}$ ed. New Delhi, India: Jaypee Brothers Medical Publishers (P) Ltd.; 2008. p. 808-10.

4. Patsnaik AK, Kodati D, Pareta SK, Patra KC, Harwansh RK. Analgesic and anti-inflammatory activities of Buchanania lanzan Spreg. Roots. Res J Pharm Biol Chem 2011;2:419-25.

5. CSIR. The Wealth of India, A Dictionary of Raw Materials and Industrial Products. Vol. 2. New Delhi, India: CSIR; 1997. p. 81.

6. Waller PJ, Thamsborg SM. Nematode control in green ruminant Production systems. Trends Prasitol 2004;20:493-7.
7. Sagwan S, Rao DV, Sharma RA. Maytenus emarginata (Willd.): A promising drug for cancer therapy. Asian J Pharm Clin Res 2011;4:177-80.

8. Ajaiyeoba EO, Onocha PA, Olarenwaju OT. In vitro anthelmintic properties of Buchholzia coriaceae and Gynandropsis gynandra extract. Pharm Bio 2001;39:217-20.

9. Kumar T, Alexander A, Dewangan D, Nagori K. Anthelmintic activity of the whole plant of Bauhinia purpurea (Linn). Asian J Pharm Clin Res 2011;4:110-1.

10. Kosalge SB, Fursule RA. Investigation of in vitro anthelmintic activity of Thespesia lampas (Cav.). Asian J Pharm Clin Res 2009;2:69-71.

11. Kundu S, Roy S, Nandi S, Ukil B, Larisha ML. In vitro anthelmintic effects of Senna Occidentalis (L.) Link (Leguminosae) on rat tapeworm Hymenolepis diminuta. Int J Pharm Pharm Sci 2015;7:268-71.

12. Chatterjee KD. Parasitology, Protozoology and Helminthology. $6^{\text {th }}$ ed. Calcutta, India: Guha Ray Sree Saraswaty Press Ltd.; 1967. p. 168-9.

13. Vigar Z. Atlas of Medical Parasitology. $2^{\text {nd }}$ ed. Singapore: P.G. Publishing House; 1984. p. 216.

14. Daniel WW. Biostatistics, A Foundation for the Analysis in the Health Sciences. $7^{\text {th }}$ ed. Singapore: John Wiley and Sons (Asia) Pvt. Ltd.; 2004. p. 312 .

15. Martin RJ. $\gamma$-Aminobutyric acid and piperazine activated single channel currents from Ascaris suum body muscle. Br J Pharm 1985;84:1445-61.

16. Niezen JH, Waghorn GC, Charlestone WA, Waghorn GC. Growth and gastrointestinal parasitism in lambs grazing either Lucerne (Medicago sativa) or Sulla (Hedysarum coronarium), which contains condensed tannins. J Agri Sci 1995;125:281-9.

17. Bate-Smith EC. The phenolic constituents of plants and their taxonomic significance, dicotyledons. Bot J Linn Soci 1968;60:325-56.

18. Martin RJ. Mode of actions of anthelmintic drugs. Vet J 1997;154:11-34.

19. Athnasiadou S, Kyriazakis F, Jackson RL. Coop. Direct anthelmic effect of condensed tannins towards different gastrointestinal nematodes of sheep: In vitro and in vivo studies. Vet Parasitol 2001;99:205-19.

20. Thomson DP, Geary TG. The structure and function of helminth surfaces. In: Marr JJ, editor. Biochemistry and Molecular Biology of Parasites. $1^{\text {st }}$ ed. New York; Academic Press; 1995. p. 203-32.

21. Satyavati GV. Use of plants drugs in Indian traditional system of medicines and their relevance to primary health care. In: Farnsworth NR, Wagner H, editors. Economic and Medicinal Plant Research. London: Academic Press Ltd.; 1990. p. 190. 